\title{
Utilization of Banks as Distribution Channels by Asset Management Companies in Indonesia
}

\author{
Alexander Franco*1, Rahmananda Fitra Feri ${ }^{2}$ \\ ${ }^{1}$ Graduate School of Business, Stamford International University, Bangkok, Thailand \\ ${ }^{2}$ Graduate School of Business, Stamford International University, Bangkok, Thailand \\ *Corresponding Author: Alexander Franco, PhD, Stamford International University, Bangkok \\ Thailand
}

Received Date: 22-06-2017

Accepted Date: 12-07-2017

Published Date: 13-07-2017

\begin{abstract}
The purpose of this study was to determine the reasons why asset management companies in Indonesia utilize banks as their major distribution channels for mutual funds. The study examined seven functions of a distribution channel: gathering of information, contacting, promotion, matching, negotiation, physical distribution, and risk taking. Managers from the top twelve asset management companies in Indonesia were surveyed using a questionnaire that consisted of close-ended Likert questions (quantitative) as well as openended questions for elaboration (qualitative). The study found that all seven functions examined had positive correlations, with the function of physical distribution being the strongest $(r s=0.844)$ and the function of matching being the least strong as per correlation ( $r=0.670)$. Descriptive statistical analysis was then applied to derive a ranking of importance among the seven functions.
\end{abstract}

Keywords: Asset management company, banks, distribution channels, Indonesia, mutual funds

\section{INTRODUCTION}

Indonesia has the largest economy in Southeast Asia with a gross national product of $\$ 2.8$ trillion (Central Intelligence Agency, 2016). It has the fourth largest population in the world, at approximately 256 million with $85 \%$ under the age of 55 (median age of 29.6) (Central Intelligence Agency, 2016).

The country has a population of 74 million who are classified as belonging to various strata of the middle class along with the wealthy (Sharpe, 2014). However, only 60 million Indonesians are believed to have bank accounts of any type (Gupta \& Dahlberg, 2015) and, according to the Indonesia Financial Services Authority (hereafter "OJK" for Indonesian name - Otoritas Jasa Keuangan), only 250,000 were investors in Indonesian mutual funds as of 2014 , or $0.4 \%$ of all bank account holders (Amianti, 2015). Banks in Indonesia provide $90 \%$ of the distribution of mutual funds in Indonesia (Kadomae, 2012). The mutual fund industry was begun in Indonesia in 1976 and until 1995 were closed- end funds. In 2014, the OJK attempted to open up distribution of mutual funds, beyond banks, to agents such as post offices, pension funds, and even pawn shops. However, this has met with very limited success.

This study is significant in that it provides the first comprehensive analysis of why Indonesian banks continue to be the preferred distributions channels for Indonesian asset management companies that sell mutual fund products. The findings can provide insights and utilitarian benefits for both asset management companies and banks that serve as distribution channels.

\section{LITERATURE REVIEW}

A distribution channel is defined as a network of people, institutions, and agencies that are involved in the flow of a product or service to customers (Easingwood \& Storey, 1996). This includes providing financial, informational, and promotional components for facilitating sales, reducing costs, and improving competitiveness (Easingwood \& Storey, 1996; Kimball \& Gregor, 1995; Thornton \& White, 2000). 
Distribution channels, serving as intermediaries, perform seven key functions as identified and defined by Kotler and Armstrong (2012). They are:

- Information: The gathering and distribution of marketing research and intelligence regarding players and forces in the marketing environment.

- Contacting: To find and communicate with prospective customers.

- Promotion: The development and spreading of persuasive communications regarding an offer.

- Matching: The shaping and fitting of an offer to a prospective buyer's needs.

- Negotiation: This involves reaching an agreement on price and other terms so that ownership can be transferred.

- Physical distribution: This relates to the transportation and storage of goods.

- Risk taking: Assuming the risks involved in carrying out the distribution channel work.

Distribution channels (also called physical distribution channels or sales channels or trade channels) constitute a vital component in effective sales management (Nag, 2013) as well as in the marketing strategy of a company (Boone \& Kurtz, 2005).

Distribution is seen as a central aspect of what an organization stands for and how it does business with its customers. Therefore, distribution strategy is at the heart of financial service organizations regarding investment choices and the likelihood of commercial success. They are often the most expensive aspect of the operational structure of a business. These channels are central to defining the type of customer base, the profit created, the appeal and attractiveness of the organization, the everyday experience of its customers, and the strength of the company brand.

As intermediaries, distribution channels utilize sales experience, networks, and customerserving skills that offer companies more value than they can obtain on their own. As intermediaries, they play a significant role in matching supply with demand by quantities of similar goods from producers and distributing them in the smaller amounts desired by customers while facilitating efficiency in delivery at the right time and place (Kotler, Armstrong, Wong, \& Saunders, 2008).

Distribution channels exist at various levels. Saxena (2005) lists four levels: zero level, one level, two level, and three level. Zero level is the least complicated where the producer connects directly with the customer. Level 1 has an agent/dealer/wholesaler as an intermediary. Levels 2 and 3 include added layers of distributors and retailers based on assessments of company resources and the overall business strategy (Mullins \& Walker, 2010). Level 1 characterizes the sale of mutual funds in Indonesia with banks as the agents of sales.

\section{RESEARCH HyPOTHESES}

This study explored the impact of the seven functions (operationalized as independent variables), as outlined by Kotler \& Armstrong (2012), on Indonesian asset management companies choosing to use banks as their main distribution channel (dependent variable). The following hypotheses were tested:

Hypothesis 1: Indonesian asset management companies choose banks as their main distribution channel due to the distribution function of gathering.

Hypothesis 2: Indonesian asset management companies choose banks as their main distribution channel due to the distribution function of contacting.

Hypothesis 3: Indonesian asset management companies choose banks as their main distribution channel due to the distribution function of promoting.

Hypothesis 4: Indonesian asset management companies choose banks as their main distribution channel due to the distribution function of matching.

Hypothesis 5: Indonesian asset management companies choose banks as their main distribution channel due to the distribution function of fee negotiations.

Hypothesis 6: Indonesian asset management companies choose banks as their main distribution channel due to the distribution function of physical distribution.

Hypothesis 7: Indonesian asset management companies choose banks as their main distribution channel due to the distribution function of risk taking. 


\section{ReSEARCH Methodology}

\section{Popullation and Sample Size}

According to the OJK (2015), there were 1,096 mutual funds in Indonesia, managed by 82 asset management companies. The top 12 companies, controlling approximately $76 \%$ of the market share were chosen as the sample size (see Table 1). The 12 were chosen with a threshold of having a net asset value of at least 5 trillion Indonesian rupiahs (IDR).

Table1. Companies in Sample Population

\begin{tabular}{|l|l|}
\hline Company Name & $\begin{array}{l}\text { Market } \\
\text { Share(\%) }\end{array}$ \\
\hline Schroder Investment Management & $19 \%$ \\
\hline BNP Paribas Investment Partners & $10 \%$ \\
\hline Bahana TCW Investment Management & $9 \%$ \\
\hline Mandiri Manajemen Investasi & $9 \%$ \\
\hline Batavia Prosperindo Aset Manajemen & $7 \%$ \\
\hline Manulife Aset Manajemen Indonesia & $5 \%$ \\
\hline Panin Asset Management & $4 \%$ \\
\hline Danareksa Investment Management & $4 \%$ \\
\hline BNI Asset Management & $3 \%$ \\
\hline Sinarmas Asset Management & $2 \%$ \\
\hline Trimegah Asset Management & $2 \%$ \\
\hline Eastspring Investments Indonesia & $2 \%$ \\
\hline
\end{tabular}

Data from Otorita Jasa Keuangan, 2015

\section{Research Instrument}

This study utilized a self-administered questionnaire that contained forced, 4-point Likert scales within closed-ended questions along with open-ended follow-up for elaboration and clarification. The forced nature of the questionnaire was due to the fact that the respondents had high familiarity (in some cases, expertise) in the subject matter being inquired upon. The questionnaires were administered over a four-month period until all twelve of asset management companies, making up the sample population, were tested. Two experienced managers were surveyed at each company for a total of 24 respondents. Though selfadministered, the questionnaires were handdelivered and then collected in person. The respondents consented and completed the questionnaires under the condition of anonymity.

Three questions were asked to test each of the seven variables. All scales in the questionnaire had a Cronbach alpha internal reliability score of over .86, indicating consistency (Hair, Black, Babin \& Anderson, 2010; Sekaran, 2000; Tavakol \& Dennick, 2011). The questionnaire was translated in Bahasa Indonesia and translated back into English to ensure accuracy and prevent semantical ambiguity (Behling \& Law, 2000; Domyei \& Taguchi, 2009; Harkness, Van de Vijer \& Mohler, 2002).

\section{RESEARCH FINDINGS}

Quantitative analysis was utilized to analyse the data obtained. Spearman's rank correlation coefficient was used to test the strength and direction (positive or negative) of the correlations between each independent variable and the dependent variable, with -1 as a perfect

Table2. Summary of Spearman's Coefficient Testing

\begin{tabular}{|l|l|l|}
\hline Functions (as variables) & Rs* $^{*}$ & Sig** \\
\hline Gather Information & .824 & 0.001 \\
\hline Contacting & .837 & 0.001 \\
\hline Promotion & .837 & 0.001 \\
\hline Matching & .670 & 0.017 \\
\hline Negotiation & .767 & 0.004 \\
\hline Physical Distribution & .844 & 0.001 \\
\hline Risk Taking & .695 & 0.012 \\
\hline
\end{tabular}

*Rs = Spearman Rank-order Coefficient

$* *$ Sig = significance level

negative correlation and +1 as perfect positive correlation; the nearer to 0 , the weaker the correlation.(Burns \& Bush, 2014; Wilson, 2014). Significance level testing then followed.

The testing indicated five strong positive relationships: physical distribution ( $\mathrm{rs}=0.844$ ), promoting ( $\mathrm{rs}=0.837)$, contacting $(\mathrm{rs}=0.837)$, gathering information ( $\mathrm{rs}=0.824)$, and negotiating ( $r s=0.767)$. The testing indicated two medium positive relationships: risk taking $(\mathrm{rs}=0.695)$ and matching $(\mathrm{rs}=0.670)$. All seven variables had alpha value significance numbers less than 0.05. Therefore, all the hypotheses were valid.

Descriptive statistical analysis was performed to determine the order of importance of the variables as per the responses on the questionnaire. The questionnaire consisted of a four-point scale measurement as follows: Level 1: Strongly Disagree; Level 2: Somewhat Disagree; Level 3: Somewhat Agree, and; Level 4: Strongly Agree.

Classification method was used to analyse the responses. Class intervals were calculated by with the following formula:

highest data value - lowest data value number of classes

$$
\frac{4-1}{4}=0.75
$$


As a result, the following ranges were created:

$1.00-1.75=$ lowest importance level

$1.76-2.50=$ low importance level

$2.51-3.25=$ high importance level

$3.26-4.00=$ highest importance level

Table3. Descriptive Statistics and Ranking

\begin{tabular}{|l|l|l|l|}
\hline Functions & Mean & SD* & Rank \\
\hline Gathering Inf & 3.5833 & .66856 & 2 \\
\hline Contacting & 3.6667 & .49237 & 1 \\
\hline Promotion & 2.6667 & .49237 & 5 \\
\hline Matching & 2.5000 & .67420 & 6 \\
\hline Negotiation & 3.2500 & .75378 & 4 \\
\hline Physical Distrib & 3.4167 & .66856 & 3 \\
\hline Risk Taking & 2.1667 & .51493 & 7 \\
\hline Overall & $\mathbf{3 . 0 3 5 7}$ & $\mathbf{. 6 0 9 2 5}$ & \\
\hline
\end{tabular}

* Standard deviation

The data presented in Table 3 reveals that three of the distribution channel functions were found to be very high (3.26 to 4.00 ) in influencing mutual funds to use banks for distribution purposes; two were found to be high (2.51 to 3.25 ) and two were found to be low (1.76 to $2.50)$.

\section{Highest}

- Contacting (3.6667 mean) Asset management companies heavily rely on the database of bank customers since banks have more access to prospective or existing customers in order to sell mutual fund products.

- Gathering information (3.5833 mean). This indicates that asset management companies heavily rely on information from banks in order to develop and refine market research and the consequential innovation of their products.

- Physical distribution (3.4167 mean). There are three major transactions involved with mutual funds: subscription, switching, and redemption. These transactions require knowledge and skill, but also as formal license as a mutual fund selling agent representative. As per OJK (2015), Indonesia has 30 institutions which are licensed to sell mutual funds. 23 of them are banks and most of the rest are securities firms. Therefore, asset management companies are heavily reliance on banks for physical distribution.

\section{High}

- Negotiations (3.2500 mean). Asset management companies are reliance on banks since banks possess the direct ability to negotiate the fees of mutual fund transactions with customers.

- Promotion (2.6667 mean). Reliance of banks by asset management companies for promoting mutual fund products is lower, through it exists through direct media or a bundling of advertising media with banks.

\section{Low}

- Matching (2.5000 mean). Variation occurs with mutual funds products including portfolio allocation, fees, charges and risks. Asset management companies are reliance on professionals within the banking outlets to provide the knowledge and skill necessary to customize their products for the consumer.

- Risk Taking (2.1667 mean). The risk to asset management companies is lessened if the bank takes the preponderance of responsibility for risk of financial loss and if it deals directly with customer complaints.

A specific set of questions constituted a portion of the questionnaire with the intent of testing the degree to which banks contributed to an increase in the number of individuals customers as opposed to institutional investors. These questions also sought to determine the degree of contribution of volume of sales from individual customers as opposed to institutional investors. The assessments made by the respondents are found in Tables 4 and 5, which reflect descriptive statistical analysis. The ranking provided is inclusive of both tables (i.e., number of customers and volume of sales as per individual versus institutional members).

Table4. Contribution by Number of Customers

\begin{tabular}{|l|l|l|l|}
\hline Type of Customer & Mean & SD* & Rank \\
\hline Individual & 2.7500 & .62158 & 2 \\
\hline Institutional & 2.3333 & .77850 & 3 \\
\hline
\end{tabular}

* Standard deviation

Table5. Contribution by Volume of Sales

\begin{tabular}{|l|l|l|l|}
\hline Type of Customer & Mean & SD* & Rank \\
\hline Individual & 3.5000 & .67420 & 1 \\
\hline Institutional & 2.0000 & .73855 & 4 \\
\hline
\end{tabular}

* Standard deviation

The data indicates that the greatest contribution was in the volume of sales through individual purchasers. The least was in the volume of sales with institutional buyers. This is due, in part, to the fact that many asset management companies 
in Indonesia conduct direct sales with institutions independently of the banks.

The second highest ranking dealt with the number of customers obtained directly through the banks, followed by the number of institutional buyers obtained through banks as distribution channels.

The qualitative data obtained from the openended portions of the questionnaire was minimal due to limited participation with this option. Respondents were required to complete the close-ended questions, but providing any elaboration regarding the questions was optional. Therefore, insufficient data existed in order to perform any robust content analysis (Collis \& Hussey, 2015).

However, there were two recurring points that were quantitatively substantive in the openended portions. The first was that asset management companies suffered a disadvantage in that management fees charged by banks often were not tied to actual sales. The second, which was also perceived to be a disadvantage by asset management firms, is that Indonesian banks often worked with several asset management companies, thus creating competition within the bank itself. Within this multi-partner environment, bank personnel often conducted sales based on direct, reward incentives provided by individual asset management firms or simply focused on products that generated the highest revenue, disregarding other products and some asset management firms in the process.

\section{CONCLUSION}

The findings of this study were determined by utilizing inferential and descriptive statistical analysis as well as a review of qualitative data. The conceptual framework sought to establish the degree to which seven key variables (functions) affected the decision of asset management companies to use banks as distribution channels. It found strong positive to medium positive correlations for all seven, thus validating the hypotheses being tested.

Through descriptive statistical analysis, this study sought to rank, in order of importance, the seven variables examined. It determined the ranking in the following order: 1) contacting, 2) gathering information, 3) physical distribution, 4) negotiation, 5) promotion, 6) matching, and 7) risk taking.

The study also found that managers of asset management firms assessed the value of banks as distribution channels to contribute most to volume of new individual customers over institutional customers and that volume of sales was greater from individual consumers over institutional ones.

Finally, qualitative feedback from the respondents indicated concern about the management fee system between asset management firms and the competition that these firms face within banks that have multipartners regarding the sale of mutual fund products.

This study was limited in that it could have had a stronger qualitative component by way of a more balanced, bi-angulated approach. The quantitative component provided solid and robust data but a stronger qualitative component could have consisted of in-depth interviews with the managers chosen as participants.

A well-structured, Likert scale questionnaire can be very successful in testing specific hypotheses. However, semi-structure interviews can allow for elicitation of specialists or experts to articulate in narratives of greater depth (Alshenqeeti, 2014; David \& Sutton, 2004; Kvale, 2003), or as Berg (2007) indicated, to "speak in their own voice and express their own thoughts and feelings." Such narratives could then be subjected to content analysis to convert to possible quantitative examination.

Currently, only 23 banks in Indonesia have permits to distribute mutual funds products. This study provides utility in its examination of the key functions that banks can provide to asset management companies. By examining each of these individual functions and the overall context of a distribution channel, nonparticipating banks can make a better assessment as to whether they may wish to become agents of sales for mutual fund products.

In 2014, the Indonesian Financial Services Authority (OJK) began the process of opening up the distribution channel role to non-banks such as post offices, pension funds, and other enterprises. This study also provides utility to those non-bank institutions in their assessment to become distribution channels. These institutions must determine if they possess the knowledge and skill to be competitive in drawing clientele.

Finally, asset management companies that currently use banks as distribution channels have an opportunity to re-assessment their current 
business strategy. Those asset management companies that do not use banks can study the dynamics of the seven functions of distribution channels to assess the use of banks as part of a future business strategy.

\section{REFERENCES}

[1] Central Intelligence Agency. The CIA world factbook 2017. New York: Skyhorse Publishing, 2016

[2] J. Sharpe, "Meet Indonesia's middle class." Sydney, Australia: Lowy Institute for International Policy, 2014.

[3] B. D. Gupta, and D. Dahlberg, "Indonesia: Getting serious about financial inclusion." Washington, DC: Institute of International Finance, 2015

[4] G. D. Amianti, Investors expected to reach $7 \mathrm{~m}$ by 2017. [Online]. Available: http://www.theja kartapost.com/nws/2015/01/20/investorsexpected-reach-7m-2017.html.

[5] D. Kadomae, 2012, The rise of retail financial services in Indonesia, Nomura Journal of Capital Markets, 3(4), 1-21.

[6] Easingwood, C., \& C. Storey, 1996, the value of multi-channel distribution systems in the financial services sector, Service Industries Journal, 16(20, 223-241.

[7] R. Kimball, \& W. Gregor, 1995, How distribution is transforming retail banking: changes leading banks are making, Journal of Retail Banking Services, 17(3), 1-9.

[8] J. Thorton, and L. White, 2000, Financial distributions channels: technology versus tradition, Journal of Professional Services Marketing, 21(2), 59-73.

[9] P. Kotler, and G. Armstrong, Principles of Marketing, $14^{\text {th }}$ ed., Upper Saddle River, New Jersey: Prentice-Hall, 2012.

[10] R. Saxena, Marketing Management, $4^{\text {th }}$ ed., New York: McGraw-Hill, 2009.

[11] J. W. Mullins and O. Walker, Marketing Management, $7^{\text {th }}$ ed., New York: McGraw-Hill, 2010.

[12] A. Nag., Sales and Distribution Management, New Delhi: McGraw-Hill Education (India) Private Limited, 2013.

[13] L. E. Boone, and D. L. Kurtz, Contemporary Marketing, Mason, Ohio: Thomson/SouthWestern, 2005.

[14] P. Kotler, G. Armstrong, V. Wong, and J. Saunders, Principles of Marketing, $5^{\text {th }}$ ed., Essex, UK: Pearson Education Limited, 2008.

[15] Otoritas Jasa Keuangan, 2015, Asset management. [Online]. Available: http://www. ojk.go.id/en/asset-managment.
[16] J. F. Hair, W. C. Black, B. J. Babin, and R. E. Anderson, Multivariate Data Analysis, $7^{\text {th }}$ ed., Upper Saddle River, NJ: Prentice-Hall International, 2010.

[17] U. Sekaran, Research Methods for Business: A Skill Building Approach, $4^{\text {th }}$ ed., New York: John Wiley \& Sons, Inc., 2000.

[18] M. Tavakol, M., and R. Dennick, 2011, Making sense of Cronbach's alpha, International Journal of Medical Education, 2, 53-55.

[19] O. Behling, and K. S. Law, Translating Questionnaires and Other Research Instruments, Thousand Oaks, CA: SAGE Publications, Inc., 2000.

[20] Z. Domyei, and T. Taguchi, Questionnaires in Second Language Research: Construction, Administration, and Processing, $2^{\text {nd }}$ ed., London: Routledge, 2009.

[21] J. A. Harkness, F. J. van de Vijver, and P. P. Mohler, Cross-Cultural Survey Methods, Hoboken, NJ: Wiley-Interscience, 2002.

[22] A. Burns, and R. Bush, Marketing Research, $7^{\text {th }}$ edition, Upper Saddle River, New Jersey: Prentice-Hall, 2014.

[23] J. Wilson, Essentials of Business Research: A Guide to Doing Your Research, Los Angeles: SAGE Publications, 2014.

[24] J. Collis, and R. Hussey, Business Research: A Practical Guide for Undergraduate and Postgraduate Students, $2^{\text {nd }}$ ed., Basingstroke, UK: Palgrave Macmillan, 2013.

[25] H. Alshenqeeti, 2014, Interviewing as a data collection method: a critical review, English Linguistics Research, 3(1), 39-45.

[26] M. David, and C. D. Sutton, Social Research; The basics, London: SAGE Publications, 2004.

[27] S. Kvale, Interviews: An Introduction to Qualitative Research Interviewing, Thousand Oaks, CA: SAGE Publications, 1996.

[28] B. L. Berg, Qualitative Research Methods for the Social Sciences, London: Pearson Education Limited, 2007. 


\section{AUTHORS' BIOGRAPHY}

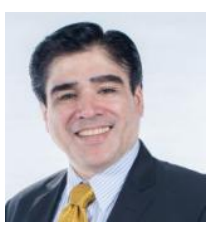

Alexander Franco, Ph.D., is a full-time senior lecturer of accounting and corporate finance at the Graduate Department of

Business, Stamford International University in Bangkok, Thailand. Dr. Franco has taught in China, Iraq, Mexico, Myanmar, the Philippines, Thailand, and the United States. He has authored several books and commissioned studies, and is on the boards of 25 scholarly journals worldwide. As a former international auditor, Dr. Franco conducted financial and operational audits on six continents in three languages.

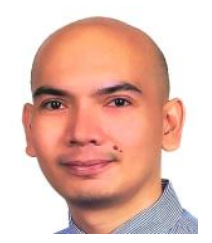

Rahmananda Fitra Feri, MBA, is an Indonesian banking professional with over a decade of experience in retail and digital banking as well as wealth management in Australia, Thailand, and Indonesia. He is fluent in English and Bahasa Indonesia and is an accomplished researcher.

Citation: Alexander, Franco, and Fitra Feri Rahmananda. "Utilization of Banks as Distribution Channels by Asset Management Companies in Indonesia." International Journal of Research in Business Studies and Management, vol 4, no. 4, 2017, pp. 1-7.

Copyright: () 2017 Alexander, Franco et al.This is an open-access article distributed under the terms of the Creative Commons Attribution License, which permits unrestricted use, distribution, and reproduction in any medium, provided the original author and source are credited. 